\title{
The role of physicians in transitional justice: combatting the aftermath of mass rape in Bosnia-Herzegovina
}

\author{
Katherine Ryken ${ }^{1}$
}

Keywords: Women's health, rape warfare, Bosnia-Herzegovina, transitional justice, post-conflict healthcare, sexual assault, human rights

\begin{abstract}
Between 1992-1995, an estimated 20,00050,000 women were raped during the war in Bosnia-Herzegovina. Twenty years later, victims of war rape continue to experience severe mental health disorders, Posttraumatic Stress Disorder (PTSD), and multiple co-morbidities. A recent comprehensive study of rape survivors who have utilized non-governmental organization (NGO) services demonstrate alarming reports of chronic gynecologic problems. The purpose of this paper is to discuss the role of war-related sexual violence in Bosnia-Herzegovina. Specifically, it will examine the role of medical professionals in post-conflict societies, through documenting human rights abuses and providing clinical care for victims.

${ }^{1}$ University of lowa, Roy J. and Lucille A. Carver College of Medicine, lowa City, lowa
\end{abstract}

\section{Introduction}

During the early years of the war in Bosnia-Herzegovina, journalists commonly used the term "ethnic cleansing" to describe the systematic rape, torture, forced resettlement, and mass killings that were utilized by the
Bosnian Serbian Army in their nationalist quest for a greater Serbia. It is estimated that between 100,000 and 250,000 people, mostly Bosnian Muslims, were killed between 1992 and 1995. $^{1}$

While these violations continued for years, it was legally unclear as to whether the actions of the Serbs constituted genocide or justification for international humanitarian intervention until July 1995, when over 8,000 Bosniak Muslim men and boys were murdered and thousands of women were rounded up and raped repeatedly in the United Nations-declared "safe zone" Srebrenica. Due to a complicated legal framework still under debate, it is difficult to determine whether or not Srebrenica was the only true case of "genocide" as defined by international law. However, it is clear that regardless of legal definitions, the atrocities committed against Bosniak Muslims in the 1990s left communities in shards of what they once were.

Please cite this paper as: Ryken $K$. The role of physicians in transitional justice: combatting the aftermath of mass rape in Bosnia-Herzegovina. Proc Obstet Gynecol. 2015;5(3):Article 2 [ 11 p.]. Available from: http://ir.uiowa.edu/pog/ Free full text article.

Corresponding author: Katherine Ryken, Roy J. and Lucille A. Carver College of Medicine, University of lowa, 375 Newton Rd, lowa City, lowa 52242, katherine-ryken@uiowa.edu

Financial Disclosure: The author reports no conflict of interest.

Copyright: (c) 2015 Ryken. This is an open-access article distributed under the terms of the Creative Commons Attribution License, which permits unrestricted use, distribution, and reproduction in any medium, provided the original author and source are credited. 
Srebrenica is often discussed and memorialized in the rhetoric surrounding the conflict. Rarely do these discussions address the thousands of women brutally raped and demoralized during the war - an estimated 20,000-50,000. One judge of the International Criminal Tribunal for the Former Yugoslavia described these rapes as a woman, "experiencing a death, and still being forced to exist".

This point is elaborated by Prof. Cybele Cochran, through the testimony of women in Sierra Leone:

"'The women in our village did not speak to the TRC [truth and reconciliation commission] because they would have to say that they had been raped not once but many times, and they were not prepared to let others know this truth about what happened to them.' Victims speak instead about what happened to others, especially the dead: husbands, brothers, sons, and relatives. It is only natural that they would share the stories for those who cannot speak for themselves, but in doing so their needs are disregarded. Hiding the complete truth disrupts access to crucial rehabilitation services. It also prevents a truth commission from accomplishing its mission of documenting the history of a conflict. Only a partial and a malecentric truth is told in the absence of women's accounts. As a result, truth commissions can become inadvertently biased towards men." 3

Due to the personal nature of the trauma endured, international stigmatization, and historical precedent, sexual violence against women often goes unreported and un-convicted. It is known as the least condemned of all war crimes.

A physician's role is unique in its ability to bring perpetrators to justice, as well as provide women with much needed medical and psychiatric care - through meticulous scientific research and by providing compassionate care for survivors of war rape.

It is the purpose of this paper to discuss how medical professionals can play an important and necessary role in providing justice for women. Specifically, this paper will examine the role of warrelated sexual violence in BosniaHerzegovina and the chronic effects this continues to have on victims. It seeks to examine the imperative role that physicians and healthcare workers can and should play in seeking justice for victims of mass rape and crimes against humanity.

\section{The Role of War Rape in Bosnia- Herzegovina}

Armed conflicts disproportionately take a toll on civilian populations particularly vulnerable are women and children. International law, however, historically provided little protection for women from sexual violence until the 1990s. Article 46 of the Hague Conventions in 1907 granted to women that their, "family honor and rights were to be respected." the fact that rape was illegal in war, but made the argument based upon a woman's honor and not rape itself as a violent crime. The Nuremburg and Tokyo Trials, too, hardly mentioned sexual violence against women, despite the fact that up to 2 million German women were raped by Soviet soldiers during the occupation of Germany. ${ }^{5}$ 
Historically, the viewpoint of leaders reflected the general consensus at the time - that rape is an inevitable byproduct of warfare, rather than part of its destructive force. Stalin reportedly stated that Yugoslavian politician Milovan Djilas, who was offended by the number of rapes occurring in his country, should "understand it if a soldier who has crossed thousands of kilometers through blood and fire and death has fun with a woman or takes some trifle."

In the early 1990s, the Yugoslav People's Army and the Bosnian Serbian Army began their campaign to reclaim Serbian areas of Bosnia for their vision of a greater Serbia. Reports of sexual violence leaking from the region were on such a huge scale as early as 1992 that it was clear systematic sexual violence against civilians was being employed by the Bosnian Serbs.

It is currently estimated that between 20,000-50,000 women and girls from Bosnia-Herzegovina were raped during the war. ${ }^{7}$ Still, this number is impossible to derive accurately, because there is no clear definition of what it measures. It is not the number of rapes that occurred, total. Women were raped repeatedly, rendering this number significantly larger. One woman testified that it would be impossible for her to count the number of times she was raped. Inclusion of the number of women who died after being raped or after subsequent beatings, and were thus unaccounted for, would cause the number to expand substantially. Further, stigmatization of victims universally causes estimates of rape victims to be low. This is especially true for societies in post-war Bosnia-Herzegovina, where survivors commonly report that stigmatization affects their daily lives and that their relationships have been significantly or completely changed since their rape. ${ }^{8}$

Given the widespread and systematic nature of the sexual violence in BosniaHerzegovina, the International Criminal Tribunal for the former Yugoslavia (ICTY) was established in May 1993. The witness accounts from the tribunal are horrific and damning. Repeated rapes (oral, anal, and vaginal), sexual enslavement, torture, and trafficking of girls from soldier to soldier were pervasive. Girls and women were kept in hotels, schools, gymnasiums, houses, and police stations. Repeated rapes and beatings sometimes resulted in death. Bosnian women reported that they were raped repeatedly until impregnated, while being told they would bear Chetnik babies for Serbia. Women were commonly enslaved until abortion was no longer possible, then finally released.

The Tribunal found that rape could constitute torture in a case in the Laśva Valley, in central Bosnia, where a witness reported that the accused threatened to insert a knife into her vagina if she did not tell the truth, and she was then raped vaginally and orally. In another town called Foća, nine women and girls ranging from 12 to 24 years of age were kept in Commander Pero Elez's house, taken out one by one, and repeatedly raped each night by multiple soldiers. Another witness says she watched her six-year-old daughter raped by three soldiers before they killed her father. A 25-year old woman recalls being raped by a soldier, who then leaned back while he smoked a cigarette and told her he would have 
done worse - but he had a daughter her age, so he held himself back. ${ }^{2}$

While the ICTY has faced much academic and international criticism for its limitations, it is important to recognize that this was the first time in history that convictions were entered for rape as a form of torture, and for sexual enslavement as a crime against humanity in international law. It was also the first Tribunal in Europe that passed convictions for rape as a crime against humanity, following a previous case adjudicated by the International Criminal Tribunal for Rwanda. ${ }^{8}$

This was the first time that sexual violence was considered to be an instrument of genocide - not a mere byproduct of war, but instead, part of the destructive force utilized by the perpetrators to degrade and dehumanize their victims and destroy their sense of ethnicity. The consideration of sexual violence as an act of genocide, the destruction of a people, should expand this from a "women's issue" to a global human rights disaster. Both rape and genocide are preventable, and thus places them under the scope of practice for all health professionals, particularly physicians.

\section{Chronic Health Implications of Mass Rape}

When a war ends, the peace treaty signed, and the international spotlight moves along- there remains thousands upon thousands of individuals whose lives are irreparably changed, and must build a new life from the destruction war leaves in its wake. The quality of life of these individuals remains significantly inferior to non-post-conflict societies for years after the end of the war. This affects the country's development Syria, for example, is estimated to have lost 35 years of development over the course of its four year long civil war. Bosnia-Herzegovina, twenty years after the end of the war, still struggles with its infrastructure, economy, and medical care.

The enormity of the trauma facing the thousands of rape survivors in BosniaHerzegovina is poorly documented indeed, although reports of rape as a war strategy in many conflicts exist, there has historically been little systematic or wide-scale research about its health effects on survivors, and even fewer regarding its chronic health consequences.

It is well documented that the experiences of war or sexual violence are two of the most predictive experiences that lead to post-traumatic stress disorder (PTSD). Therefore survivors of war rape not only experience sexual violence, but commonly the equally traumatizing experiences of murdered family members, forced expulsion, or losing their homes. This creates a multilayered trauma that leads to an extremely high proportion of survivors suffering from severe mental health disorders, and more pronounced symptoms of PTSD. ${ }^{9}$ PTSD in these patients is typically associated with multiple comorbidities, including depression, somatization, and anxiety disorders. ${ }^{10}$ In addition, post-war stressors play a large role in exacerbating PTSD symptomology this has been underlined by several studies in Bosnia-Herzegovina that showed common findings in post-conflict 
societies, such as poverty, unemployment, ineffectual government, and impunity, pose additional serious threats to the mental health of survivors. $^{11}$

Studies of rape survivors, considered to be conducted in "civilian" settings, or not associated with war, have generated a typical list of signs and symptoms that are commonly associated with sexual violence. These include reproductive health problems, pain syndromes, eating disorders, gastrointestinal disorders, as well as increased rates of chronic diseases such as diabetes, arthritis, and headaches. ${ }^{12}$ Sexually transmitted diseases and unwanted pregnancies are also common consequences of rape. ${ }^{13}$ Survivors commonly report problems and anxiety with sex- likely stemming from the fact that rape, above all, is forced intrusion of a perpetrator into a woman's body, in an area that is specifically associated with her sexual identity and sexuality. ${ }^{14}$

Research specifically on war rape with survivors in Albania, Kosovo, and Bosnia-Herzegovina in 1993 demonstrated similar findings to that of rape not associated with war. Additionally, survivors exhibited high levels of rectal and genital injuries, bladder and rectal insufficiency, fistulas, and sexually transmitted diseases. Researchers also noted increased rates of pre-cancerous dysplasia or carcinoma of the cervix, carcinoma of the inner genitals, and breast cancer. ${ }^{8}$

Medica Zenica, one of several nongovernmental organizations that provide services to survivors of war rape, published the most comprehensive study in the region on the chronic health effects of war-related sexual violence in 2014. In the study, interviewers approached 51 survivors of rape who have utilized Medica Zenica's medical and psychological services since 1993 and administered psychometric measures and a questionnaire. The findings, director Sabiha Husic wrote, indicated that the "psychological and health situation of most survivors of war rape remains extremely alarming": 57\% of participants currently suffer from clinically relevant PTSD symptoms. 70\% state that the rape experience completely affects their life today. $65 \%$ of participants regularly take drugs; half of them for 20 years. Almost all of the participants take psychopharmacological medicine. More than $58 \%$ of the participants reported the presence of four or more gynecological problems and almost $11 \%$ reported cancer. ${ }^{8}$

The report also identified that relationships between survivors and their families, particularly husbands and children, are significantly affected $-76 \%$ of women stated that the rape has influenced their relationship with men in general or their husbands today, 20 years later. One woman answered that, "I don't have any wish or need for sex, and of course I have never told this to my husband nor could I ever tell him." Another said, when asked how it had affected her relationship with her children, she said, "I never spoke about it with them in detail; they just know what happened to me. Simply they don't like to speak about it either."

\section{The Current Landscape and Potential for Physicians in Transitional Justice}

The concept of transitional justice is one 
that addresses the aftermath of systematic human rights abuses in communities. This ideology recognizes that, on a huge scale and in many ways, post-conflict communities that have experienced genocide, crimes against humanity, or war crimes require years of transition to stability and that victims deserve justice to be established during these years. The term originated in the early 1990s, primarily in response to drastic changes in the political landscapes in Latin American and Eastern Europe and the demand for justice in these regions.

In international law, the 1988 decision of the Inter-American Court of Human Rights in Velasquez Rodriguez vs. Honduras found that all states have four fundamental obligations in the area of human rights to uphold transitional justice. These include: 1) to take reasonable steps to prevent human rights violations; 2) to conduct a serious investigation of violations when they occur; 3) to impose suitable sanctions on those responsible for the violations; and 4) to ensure reparation for the victims of the violations. Transitional justice is, by necessity, a holistic approach through all of these obligations.

Following the Dayton Accord in 1995, which effectively ended the war in Bosnia-Herzegovina and still governs the country under its constitution, the ability of the government to function productively has been crippled by an ineffective rotating presidency and everincreasing bureaucracy, combined with a struggling economy. The ability to exert transitional justice through the state has been mostly ineffectual. It has therefore fallen upon non-governmental organizations to provide the care that survivors require. The state should and must contribute to providing justice for victims - though this has yet to come to fruition in Bosnia-Herzegovina.

Thus, in the absence of state involvement, there exists the potential for healthcare professionals to provide transitional justice through conducting scientific research and providing medical and psychological reparation for victims.

The potential of epidemiology and scientific research in human rights violations has historically been underutilized, though the implications of collecting epidemiological data following mass atrocity is of critical import to both validating the experience of survivors and evaluating the impact of human rights violations. Such studies can also generate evidence to support policy decisions during and after conflict. They generate quantifiable data of illnesses, morbidity, and mortality - establishing a concrete measurement of the quality of life experienced by survivors that can be understood by lawmakers and those involved in policy-making. ${ }^{15}$ And because physicians are in the role of providing care, they also operate within a window of unique opportunity to record the experiences and health conditions of victims.

Given the hope that the state will eventually become more involved in the provision of justice-seeking measures, such studies can be utilized in formulating new governance. Retrospective studies in particular are of use in such areas, employing standardized questionnaires about past events. Studies during conflicts that 
employ similar methodologies are often difficult or impossible to obtain - and because little research has so far been conducted regarding women's experiences of sexual violence in the region, it is important that these studies are done now, even 20 years after the war.

Unfortunately, the collaboration between human rights groups and scientific research is currently lacking. Many human rights groups, such as Human Rights Watch, focus primarily on legal action with little focus on quantitative methods of epidemiology or sampling. This is a prime opportunity for collaboration. By combining international law with science and medicine, transitional justice may be carried out more swiftly, effectively, and conclusively.

Scientific research, then, can play an important role in providing evidence against perpetrators. In 2002, Physicians for Human Rights published a report on the experiences of displaced persons in Sierra Leone. ${ }^{18}$ The survey was able to establish from the women who were sexually abused, that the primary rebel group, the Revolutionary United Front (RUF), was systematically committing rape on a wide scale. Physicians for Human Rights has conducted similar surveys on events in Kosovo, Afghanistan, and Iraq. This type of study could be used in order to bring the perpetrators of war crimes to justice.

Epidemiologists can also provide needsbased assessments - this is critical for evaluating the needs of this community. In terms of policy, immediate postconflict surveys that establish a baseline on health conditions are of importance in evaluating the recovery of a country's infrastructure and health system. With follow-up studies to track improvements, we can aim to provide a reliable data set of public health parameters in postconflict communities.

Mental health care, which is not commonly discussed but integral to an understanding of war-related rape, must be provided for in a model of transitional justice. Post-genocidal communities are at increased risk for a repeated genocide. Other risk factors include poor economic status, government corruption, conflict history, and social fragmentation - all of which exist in current Bosnia-Herzegovina. A study in Rwanda in 1994 demonstrated that individuals who experienced multiple traumatic events were less likely to support justice and reconciliation projects on both a national and local level. ${ }^{16}$ Another study among Kosovar Albanians, after the war from 19981999, demonstrated an association between traumatic war-related events, decreased mental health, impaired social functioning, and strong respondent emotions of hatred and revenge toward Serbs. ${ }^{17}$ Given the level of PTSD and psychological distress both in survivors of rape and the general public of Bosnia-Herzegovina, it is not surprising that there remains a divided society amongst Bosniaks, Croats, and Serbs. All of these are risk factors for repeated conflict with the potential for genocide, including genocide through acts of sexual violence. By improving the quality of mental healthcare for all individuals, we can alter the divisive risk factors in post-conflict communities.

Finally, the provision of clinical care for 
survivors is necessary for rehabilitation. Victims of sexual assault require access to quality services for both physical and psychological trauma. Unfortunately, this is not often a priority in post-conflict societies. The well-being of women in society is understood to be linked to social and economic development of nations. $^{3}$ Without rehabilitation, women are unable to rejoin society fully. It is therefore critical that healthcare providers are involved in discussions of transitional justice - to both provide effective rehabilitation as well as document crimes.

Survivors of sexual violence should be entitled to quality healthcare provided by the state. It is important to note that while $79 \%$ of participants in Medica Zenica's study in the Federation of Bosnia-Herzegovina have achieved unique status of "civilian victim of war," the overwhelming majority stated that governmental institutions do nothing for survivors and that essential support is provided exclusively by NGOs. Medica Zenica's key informant focus groups with relevant NGOs revealed that the rights under this status has been, in reality, reduced to a monthly payment of 550 BAM (about \$300). The other rights that should legally be provided, including healthcare support and social needs, are not being realized in practice. This status also does not guarantee that survivors have a right to health insurance, and even if they do, it is often not on the level as other groups traumatized by the war.

The survivors of sexual violence during the war require the same care as other individuals--in addition, the quality of healthcare in Bosnia-Herzegovina must be improved to pre-conflict standards to improve the quality of health for survivors. By separating marginalized groups from others to receive care from NGOs as opposed to their local hospital, the stigmatization that women commonly feel is being enforced and upheld. It is the level of separation and isolation that these women face that must be addressed. The majority of survivors in Bosnia-Herzegovina report that they often feel blamed, discriminated against, or judged within the healthcare system. This experience is explained by Koss and Harvey (1991), who state sexual violence is a crime often met with reactions that further traumatize victims:

"Sexual assault does not occur in social and cultural isolation: we live in a rapeprone culture that propagates messages that victims are to blame for the assault, that they caused it and indeed deserve it. Victims are faced with negotiating post-assault help seeking and ultimately their pathway to recovery within multiple hostile environments. If victims turn to formal systems, such as the legal, medical, and mental health systems, they may face disbelief, blame, and refusals of help instead of assistance. The trauma of rape extends far beyond the actual assault, and society's response to this crime can also affect women's well-being." 14

This can be combatted on an individual level, through positive interactions with healthcare workers--such experiences were cited by survivors as validating interactions that allowed them to seek out medical attention again in the future. One survivor recalls her physician saying to her, "Whatever I say to you I know I can't heal your wounds. How do I estimate this to you, or to any other 
Proceedings in Obstetrics and Gynecology, 2015;5(3):2

woman?" Another survivor offers the following advice to other survivors: "To get help from doctors, psychologists, to turn to an institution or an NGO." Medica Zenica was commonly cited as the first place survivors turned to for safety, medical care, surgery, or the need to testify. ${ }^{8}$

Women's groups and organizations must be strengthened, funded, and supported by a wide range of staff. There are currently at least three primary non-governmental organizations in Bosnia-Herzegovina that provide healthcare specifically for survivors of war rape - Medica Zenica, Vive žene, and Snaga žene. All of these are local, rather than international. Despite the fact that this responsibility lies with the state according to international human rights law, Medica Zenica alone has provided 400,000 instances of care for women since its foundation in 1993. This organization, based upon the German feminist organization 'medica mondiale,' and founded by a German gynecologist, follows a feminist research paradigm and has been instrumental in providing care through mobile programs and primary care exams. Snaga žene's work is focused on displaced populations - refugee settlements in Višca, Jezevac, and Karaula in Tuzla canton, and returnee communities in Mahala, Osmaci, and Srebrenica in the Eastern Republic of Srpska. Vive žene is primarily focused upon rehabilitation and psychotherapy. Groups such as these not only provide services for women - they lobby upon their behalf, ensuring that the interests of rape survivors are represented.

\section{Conclusions}

The sexual violence against women in Bosnia-Herzegovina was not unprecedented, nor was it the last example of such. Recent conflicts in Rwanda, Sierra Leone, and Sri Lanka have produced reports of systematic rapes--and now, reports are surfacing that women are being systematically raped and enslaved by the Islamic State. There is an urgent need for systematic surveillance of these reports, through public health and epidemiological studies to assess their incidence and current humanitarian needs. This can then be combined with international law to appropriately address intervention.

The current landscape of transitional justice within Bosnia-Herzegovina is an example of a conflict zone that has been left with an ineffective government, poor economy, and individuals in great need of clinical care. It demonstrates that physicians can be an important part of transitional justice, universally. While operative NGOs providing specialized healthcare are consistently rated favorably by survivors, this is insufficient considering the vast number of women who continue to be affected by sexual violence during the war. In order to secure the success of transitional justice in Bosnia-Herzegovina, it is essential that the public and private sectors utilize physicians fully as both researchers and care providers.

\section{References}

1. R. Rosner, Powell S. Post-traumatic growth in times of war. In: Tedeschi RG, Calhoun LG, editors. Handbook of Posttraumatic Growth. Mawah, NJ: Lawrence Erlbaum Associates; 2006. 
2. Jelacic D, Barsony R. Sexual violence and the triumph of justice [DVD]. The Netherlands: An International Criminal Tribunal for the former Yugoslavia (ICTY) Outreach Programme and ITSS Production; 2011.

3. Cochran C. Transitional justice: Responding to victims of wartime sexual violence in Africa. Journal of International Policy Solutions. 2008 MarApr;9:33-39.

4. International Conferences (The Hague), Hague Convention (IV) Respecting the Laws and Customs of War on Land and Its Annex: Regulations Concerning the Laws and Customs of War on Land, 18 October 1907, available at: http://www.refworld.org/docid/4374cae6 $\underline{4 . h t m l}$ [accessed 3 November 2015].

5. Heineman E. The hour of the woman: memories of Germany's crisis years and West German national identity. American Historical Review. 1996;101(2):354-395. doi: 10.1086/ahr/101.2.354

6. Applebaum A. Iron Curtain: The Crushing of Eastern Europe, 19441956. New York, NY: Doubleday; 2012.

7. Crowe D. War crimes, genocide and justice: a global history. New York, NY: Palgrave MacMillan; 2013.

8. Husic, S, Siljak I, Osmanovic E, Dekic F, Heremic L. We are still alive: research on the long-term consequences of war rape and coping strategies of survivors in Bosnia and Herzegovina. Zenica, Bosnia and Herzegovina : Medica Zenica; 2014. http://www.medicamondiale.org/fileadmi n/redaktion/5 Service/Mediathek/Doku mente/English/Documentations studies/ 141128 Research We-Are-StillAlive CR-Medica-Zenica medicamondiale.pdf
9. Folnegovic-Smalc V. Psychiatric aspects of the rapes in the war against the republics of Croatia and BosniaHerzegovina. In: Stiglmayer A, editor. .) Mass rape: the war against women in Bosnia-Herzegovina. Lincoln, NE: University of Nebraska Press; 1994. p. 174-179.

10. Klarić M, Francisković T, Klarić B, Kresić M, Grković J, Lisica ID, Stevanović A. Social support and PTSD symptoms in war-traumatized women in Bosnia and Herzegovina. Psychiatr Danub. 2008 Dec;20(4):466-73. PubMed PMID: 19011587.

11. Powell S, Duraković-Belko E, editors. Sarajevo 2000: the psychosocial consequences of war. Results of empirical research from the territory of former Yugoslavia. Presentations from a Symposium held at the Faculty of Philosophy; 2000 July 7-8; Sarajevo, Bosnia and Herzegovina. UNICEF; 2002. http://psih.org/2000e.pdf.

12. International Center for Transitional Justice. Transitional Justice In Focus. New York, NY: International Center for Transitional Justice; 2009. Accessed $2015 \quad$ Mar 12. https://www.ictj.org/about/transitionaljustice

13. Astbury J. Services for victim/survivors of sexual assault: Identifying needs, interventions, and provision of services in Australia. Australia Center for the Study of Sexual Assault Issues, 6. Melbourne, Australia: American Institute for Family Sciences; 2006.

14. Koss MP, Harvey MR. The rape victim: clinical and community interventions. Newbury Park, CA: Sage Publications; 1991.

15. Thoms ON, Ron J. Public health, conflict and human rights: toward a collaborative research agenda. Confl Health. $2007 \quad$ Nov 15;1:11. http://dx.doi.org/10.1186/1752-1505-111 PubMed PMID:18005430. 
16. Pham PN, Weinstein HM, Longman $\mathrm{T}$. Trauma and PTSD symptoms in Rwanda: implications for attitudes toward justice and reconciliation. JAMA. 2004 Aug 4;292(5):602-12. http://dx.doi.org/10.1001/jama.292.5.602 PubMed PMID: 15292086.

17. Lopes Cardozo B, Vergara A, Agani F, Gotway CA. Mental health, social functioning, and attitudes of Kosovar Albanians following the war in Kosovo. JAMA. 2000 Aug 2;284(5):569-77. http://dx.doi.org/10.1001/jama.284.5.569 PubMed PMID: 10918702.

18. Physicians for Human Rights. ). WarRelated Sexual Violence in Sierra Leone: A Population-Based Assessment. Boston, MA: Physicians for Human Rights; 2002. https://s3.amazonaws.com/PHR Report s/sierra-leone-sexual-violence-2002.pdf

19. Stein MB, Barrett-Connor E. Sexual assault and physical health: findings from a population-based study of older adults. Psychosom Med. 2000 NovDec;62(6):838-43.

http://dx.doi.org/10.1097/00006842200011000-00014 PubMed PMID: 11139004. 